\title{
DETECTION OF HELICOBACTER ANTIGEN IN STOOL SAMPLES AND ITS RELATION TO H. PYLORI POSITIVE CHOLECYSTITIS IN EGYPTIAN PATIENTS WITH CHRONIC CALCULAR CHOLECYSTITIS
} By

\author{
EHSAN H. HASSAN ${ }^{1}$, SHAWKAT S.GERGES ${ }^{2}$, REHAB AHMED ${ }^{3}$, \\ ZEINAB M.MOSTAFA ${ }^{4}$, AZZA HASSAN ${ }^{5}$, HAGER ABD AL-HAMID ${ }^{5}$, \\ HEBA ABD EL-GALIL ${ }^{6}$ AND SUZAN THABET ${ }^{1}$
}

Department of Pathology ${ }^{1}$, Department of Surgery ${ }^{2}$, Department of General Medicine Department of Radiology ${ }^{4}$, and Department of Medical Parasitology \& Immunology ${ }^{5}$, National Hepatology and Tropical Medicine, Research Institute ${ }^{1,2,3,4,5}$, Cairo, and Department of Community6, Faculty of Medicine, Al-Azhar University, Cairo, Egypt ( ${ }^{*}$ Corresponding author: e-mail:rehabahmed71@yahoo.com)

\section{Abstract}

Evidences supporting the association between $H$. pylori infection and chronic cholecystitis could be found by using direct culture or staining of $H$. pylori in gallbladder tissues as well as indirect techniques. Stool antigen test has been widely used due to its non-invasive nature. Various stool antigen tests were developed to detect $H$. pylori using an enzyme immunoassay (EIA) based on monoclonal or polyclonal antibodies

This study evaluated the frequency of $H$. pylori antigen in stool samples of patients with chronic calcular cholecystitis as regard gall bladder histopathological changes. -Fifty patients were included presented with symptomatic cholecystolithiasis recruited from the outpatient clinic of National Hepatology and Tropical Medicine Research Institute during 2014-2015. Full history and clinical examination and abdominal ultrasonography were performed. Stool samples were collected, prepared and examined for detection of $H$. pylori antigen. Cholecystectomy was done for all patients; 45 patients $(90 \%)$ by laparoscopic Cholecystectomy and 5 patients $(10 \%)$ by open surgery and removed gallbladders were submitted to pathology department for detection of $H$. pylori in tissue under microscope using Giemsa stain. The results showed that $(82 \%)$ were females with mean age (42.6+1years). The mean BMI was $(29+7.2)$ H. pylori-specific antigen in stool samples was detected in $40 \%$ of patients and $38 \%$ were detected in patients; tissue, with significant correlation between $\mathrm{H}$. pylori-specific antigen in stool and in tissue. Histopathological pictures infection in tissue were $68.4 \%$ mucosal erosions, $63.2 \%$ mucosal atrophy, $57.9 \%$ mucosal hyperplasia, $26.3 \%$ metaplasia, $42.1 \%$ musculosa hypertrophy, $26.3 \%$ fibrosis, but lymphoid aggregates were in $42.1 \%$ of cases.

Key words: Helicobacter pylori, chronic calcular cholecystitis, ELISA, histopathology.

\section{Introduction}

Helicobacter pylori, a gram-negative bacterium found on the luminal surface of the gastric epithelium, was first isolated in 1983 (Warren et al,1983).Infection with $H$. pylori is a cofactor in the development of three important upper gastrointestinal diseases: duodenal or gastric ulcers(El-Omar et al,1995), gastric cancer (Hansen et al,1999), and gastric mucosa-associated lymphoid-tissue (MALT) lymphoma (Parsonnet et al,1994). It was thought that $H$. pylori pathogenic effects were limited to the stomach, however, its existence in extra gastric structures was reported (El-Fakhfakh et al, 2014). Helico- bacter pylori and $H$. bilis were detected in the bile and gallbladder in $75 \%$ of patients with gallbladder cancer and more than $50 \%$ with chronic cholecystitis (Murphy et al, 2014). Evidences supporting association between $H$. pylori and chronic cholecystitis were demonstrated by direct culture or staining of gallbladder tissues and by PCR, ELISA using $H$. pylori-specific genes or antibodies (Lee et al, 2010).

Various stool antigen tests were widely used due to their non-invasive nature tests for detection of $H$. pylori as the enzyme immunoassay (EIA) based on monoclonal or polyclonal antibodies (Gisbert et al, 2004). 
A systematic review of the stool antigen test in untreated patients with $H$. pylori showed overall sensitivity; 91\%, specificity; 93\%, positive predictive, $92 \%$ and negative one; 87\% (Gisbert et al, 2006). The Warthin stain showed $H$. pylori existence in $13.5 \%$ (524) of gall-bladders mucosa in cholecystitis patients (Dong et al, 2007). So, it was an important discovery when a few investigators found $H$. pylori in some gallbladders of some patients with chronic cholecystitis that could be a key factor (Kawaguchi et al, 1996). The presence of $H$. pylori in the biliary tract was in 50-60\% of patients (Ghzal et al, 2001). H. pylori in the gastric and duodenal mucosa are much more common. In Egypt and other countries, H. pylori were $80 \%$ of population (WGO 2011). Chronic cholecystitis was commonly associated with gallstone disease and cholecystitis and gallstones caused epithelial hyperplasia of gallbladder mucosa or cancer (Jafri et al, 2010).

This study evaluated the H. pylori antigen in stool samples of patients with chronic calcular cholecystitis and its relation to histopathological changes of gall bladder.

\section{Patients, Materials and Methods}

This was a descriptive cross sectional study carried on 50 patients; 9 males \& 41 females with symptomatic cholecystolithiasis complain of dyspepsia and/or right upper hypochondrial pain recruited from the National Hepatology and Tropical Medicine Research Institute (NHTMRI) outpatient clinic from June 2014-June 2015. The recruitment and experimental protocol study was approved by NHTMRI Ethical Committee. Patients with acute cholecystitis, tumors and/or previously treated with antibiotics and proton pumb inhibitors were excluded

After full history and clinical examination; abdominal ultrasonography was done to confirm calcular cholecystitis performed by expert radiologist. Small piece of stool samples ( $\sim 5 \mathrm{mmin}$ diameter; $\sim 150 \mathrm{mg})$ added and diluted into $1 \mathrm{ml}$ of sample treatment solution in a test tube and mixed thoroughly.
H.pylori infection was detected by -specific antigens in stool sample (fecal antigen test) and by ELISA (commercially available).

Purified $H$. pylori antibody was coated on surface of microcells. An aliquot of diluted stool sample was added to wells, and the $H$. pylori antigens, if present, bind to the antibody. Unbound materials were washed. After adding enzyme conjugate, it binds to antibody-antigen complex. Excess enzyme conjugate was washed and TMB Chromogenic substrate was added. The enzyme conjugate catalytic reaction stopped at a specific time, and the color generated intensity was proportional to antigen amount, and read by a micro well reader compared in a parallel manner with calibrator and controls. Interpretation: negative $<15 \mathrm{ng} / \mathrm{ml}$, positive $>20 \mathrm{ng} / \mathrm{ml}$, Borderline: $15-20 \mathrm{ng} / \mathrm{ml}$

Cholecystectomy was done for all patients, $45(90 \%)$ by laparoscopic cholecystectomy and five $(10 \%)$ by open surgery. The gallbladders were submitted for histopathological detection of $H$. pylori in tissue samples. Gallbladder tissue samples were fixed in $10 \%$ buffered formalin, embedded in paraffin wax 5- $\mu \mathrm{m}$ thick sections and stained with hematoxylin and eosin, with Giemsa and sealed with DPX mount.

Statistical analysis: Data coding was done manually, and analyzed by SPSS program version 16. Descriptive and analytical analyses were done. Mean standard deviation "SD" that measured central tendency and dispersion of quantitative data and expressed in numbers and percentage. Analytical statistics using test of significance as: aUnpaired $t$-test: for quantitative data of two independent samples, b-Chi square-test $(\chi 2)$ to compare qualitative data, and correlation coefficient was done. The level of significance was taken at $\mathrm{p} \leq 0.05$

\section{Results}

The range of age was 18-61 (mean age $42.6 \pm 11$ years), $52 \%$ of patients were from urban areas. The mean BMI was (29 \pm 7.2$)$, most of patients were obese $(44 \%)$, the mean 
cholesterol level was $219 \pm 145$, and the mean of triglycerides was $121 \pm 52$. H. pylori-specific antigen in stool samples was detected in $40 \%$ of patients while it was detected in tissue in $38 \%$ of patients. The most predominant histopathological finding was musculosa hypertrophy (22/50) varied from mild (7/50), moderate (10/50) and severe $(5 / 50)$. Other changes as mucosal atrophy (42\%) varied from mild (24\%) to moderate $(18 \%) \&$ mucosal erosion (42\%) while lymphoid aggregates all through the mucosa $(24 \%)$, fibrosis of the gallbladder wall $(22 \%)$, mucosal hyperplasia $(36 \%)$ varied from mild (26\%), moderate (10\%), metaplasia $(10 \%)$ and dysplasia $(6 \%)$ with mild degree $(4 \%)$ to moderate $(2 \%)$.

According to the presence or absence of $H$. pylori antigen in stool, patients were divided in two groups: GI (Ag+ve in stool) $80 \%$ females, with a mean age of 44.2 years, of which $65 \%$ were from urban areas, in GII (Ag -ve in stool), 83.3 females with a mean age of 41.5 years $53.3 \%$ were from rural areas, without significant difference as regard sex, mean age and residence, with BMI higher among GI $\left(31.7 \mathrm{Kg} / \mathrm{m}^{2}\right)$ than GII $\left(27.1 \mathrm{Kg} / \mathrm{m}^{2}\right)$ with significant $(\mathrm{p}=0.02)$. Cholesterol level was higher in GII $(247 \mathrm{mg} / \mathrm{dl})$ than GI $(177.8 \mathrm{mg} / \mathrm{dl}) \&$ mean triglycerides was higher in GI $(127 \mathrm{mg} / \mathrm{dl})$ than GII $(116$ $\mathrm{mg} / \mathrm{dl}$ ), but without significant difference. GI (65\%) had mucosal erosions, but GII, (26.7\%) had erosions; GI (65\%) had mucosal atrophy but GII (30\%) had atrophy, and GI $(40 \%)$ had mucosal hyperplasia but GII (33.3\%) had hyperplasia. GI (15\%)had metaplasia, but GII (6.7\%)had metaplasia, GI (40\%) had musculosa hypertrophy and(4\%) had fibrosis but GII (46.7\%) had hypertrophy and $(23.3 \%)$ had fibrosis; cases with lymphoid infiltration were $(35 \%)$ in G1 and (16.7\%) in GII, without significant difference except for mucosal erosion and mucosal atrophy were significance $(\mathrm{p}=0.007 \&$ 0.02 respectively). While according to comparison between patients with $\mathrm{H}$. pylori $+\mathrm{ve}$ and $H$. pylori - ve in tissue, patients were divided into two groups: GI (+ve in tissue), $78.9 \%$ were females, with a mean age of 46.2 years, $68.4 \%$ were from urban areas, in GII (-ve in tissue), $83.9 \%$ were females with a mean age of 40.4 years $51.6 \%$ were from rural areas, without significant difference as regarded sex, mean age and residence. BMI mean was higher in GI $\left(30.6 \mathrm{Kg} / \mathrm{m}^{2}\right)$ than GII $\left(28 \mathrm{Kg} / \mathrm{m}^{2}\right)$ without significance, mean of cholesterol level was higher in GII $(244 \mathrm{mg}$ /dl) than GI (179mg/dl) and mean triglycerides was higher in GI $(125 \mathrm{mg} / \mathrm{dl})$ than GII $(118 \mathrm{mg} / \mathrm{dl})$ without significant difference between both groups. GI $68.4 \%$ had mucosal erosions, in GII, $25.8 \%$ had erosions. GI, $63.2 \%$ had mucosal atrophy while GII, $32.3 \%$ had mucosal atrophy, GI $(57.9 \%)$ had mucosal hyperplasia while in GII $(6 \%)$ had hyperplasia, in GI $(26.3 \%)$ had metaplasia, and none in GII.GI (42.1\%) had musculosa hypertrophy and $(26.3 \%)$ had fibrosis, GII (45.2\%) had hypertrophy and(19.4\%) had fibrosis. GI all with lymphoid infiltration were $(42.1 \%)$, GII $(12.9 \%)$ with significant differences regarding mucosal erosions $(p=0.003)$, mucosal atrophy $(p=0.03)$, mucosal hyperplasia $(\mathrm{p}=0.012)$, metaplasia $(p=0.003) \&$ lymphoid infiltration $(p=0.02)$. There was significant correlation between $H$. pylori-specific antigen in stool and in tissue.

\section{Discussion}

In the present study, fifty patients were included; all presented with symptomatic cholecystolithiasis with mean age was (42.6 \pm 1 1years) ranged from 18-61 years. The majority of patients (82\%) were females. H. pylori infection was detected by identifying $H$. pylori -specific antigens in stool samples and detection of $\mathrm{H}$. pylori in all gallbladder tissue specimens under microscope using Giemsa stain. H. pylori specific antigen in stool samples was detected in $40 \%$ of patients while it was detected in tissue in $38 \%$ of patients. This agreed with Cintia et al. (2003) who found Helicobacter DNA in $42.9 \%$ of gallbladder tissue of 46 Brazilian patients with choleli- 
thiasis and18 without cholelithiasis. Apostolov et al.(2005) found Helicobacter DNA in $16 / 22(73 \%)$ of gallbladders of Ukrainian patients with cholecystitis by immunohistochemistry. In Egypt Fekry et al.(2014) reported that gastroscopy with gastric or duodenal $H$. pylori urease test and in serum were done for 140 patients before operation. After cholecystectomy, gastric rapid urease test was positive in $40.7 \%$. The gallbladder rapid urease test was positive in $25 \%$. In 24 patients both gastric and gallbladder mucosa tested positive for rapid urease test. In 28 patients, the gastric urease test was positive while the gallbladder mucosa tested negative. In 13 patients, the gallbladder mucosa tested positive while the gastric mucosa was negative. There was a significant correlation between the rapid urease test in the gallbladder and gastric or duodenal mucosa $(\mathrm{P}=0.002)$. Modified Geimsa stained specimens revealed that H.pylori -like bacteria were detected in $63.6 \%$. There was a significant correlation between gallbladder examination of mucosa stained with Geimsa stain and gallbladder rapid urease test $(\mathrm{P}<0.001)$, but not correlated with the gastric urease test $(\mathrm{P}=0.210)$.

Table 1: General characteristics of studied sample $(\mathrm{N}=50)$ :

\begin{tabular}{|l|l|l|}
\hline Items & Chronic cellular cholecystitis patients \\
\hline Range of age (years) Mean $( \pm \mathrm{SD})$ & $18-61(42.6 \pm 11)$ & $82.0 \%$ \\
Female & 41 & $18.0 \%$ \\
Male & 9 & $48.0 \%$ \\
\hline Rural residence & 24 & $52.0 \%$ \\
Urban residence & 26 & \\
\hline BMI mean ( \pm SD) & $29 \pm 7.2$ & $6.0 \%$ \\
\hline BMI class -Under weight $\quad$-Normal & 3 & $26.0 \%$ \\
& 13 & $24.0 \%$ \\
Obese Overweight & 12 & $44.0 \%$ \\
\hline Cholesterol level mean (mg/dl \pm SD) & 22 & \\
\hline Triglyceride level mean (mg/dl \pm SD) & $219 \pm 145$ & $40.0 \%$ \\
\hline H. pylori in stool positive & $121 \pm 52$ & $60.0 \%$ \\
H. pylori in stool negative & 20 & $38.0 \%$ \\
\hline H. pylori in tissue positive & 30 & $62.0 \%$ \\
H. pylori in tissue negative & 19 & \\
\hline
\end{tabular}

Table 2: Histopathological findings of patients:

\begin{tabular}{|c|c|c|c|c|}
\hline Histopathology & Degree & Number & Percent & Total \\
\hline Mucosal erosion & $\begin{array}{l}\text { Positive } \\
\text { Negative }\end{array}$ & $\begin{array}{l}21 \\
29\end{array}$ & $\begin{array}{l}42.0 \\
58.0\end{array}$ & \\
\hline Mucosal atrophy & $\begin{array}{l}\text { Mild } \\
\text { Moderate } \\
\text { No }\end{array}$ & $\begin{array}{l}12 \\
9 \\
29\end{array}$ & $\begin{array}{l}24.0 \\
18.0 \\
58.0\end{array}$ & $21(42.0 \%)$ \\
\hline Mucosal Hyperplasia & $\begin{array}{l}\text { Mild } \\
\text { Moderate } \\
\text { No }\end{array}$ & $\begin{array}{l}13 \\
5 \\
32\end{array}$ & $\begin{array}{l}26.0 \\
10.0 \\
64.0\end{array}$ & $18(36.0 \%)$ \\
\hline Metaplasia & $\begin{array}{l}\text { Yes } \\
\text { No }\end{array}$ & $\begin{array}{l}5 \\
45 \\
\end{array}$ & $\begin{array}{l}10.0 \\
90.0\end{array}$ & \\
\hline Dysplasia & $\begin{array}{l}\text { Mild } \\
\text { Moderate } \\
\text { No } \\
\end{array}$ & $\begin{array}{l}2 \\
1 \\
47 \\
\end{array}$ & $\begin{array}{l}4.0 \\
2.0 \\
94.0 \\
\end{array}$ & $3(6.0 \%)$ \\
\hline **Lymphoid Infiltration & $\begin{array}{l}\text {-All through } \\
\text {-No }\end{array}$ & $\begin{array}{l}12 \\
38 \\
\end{array}$ & $\begin{array}{l}24.0 \\
76.0 \\
\end{array}$ & \\
\hline Musculosa Hypertrophy & $\begin{array}{l}\text { Mild } \\
\text { Moderate } \\
\text { Severe } \\
\text { No } \\
\end{array}$ & $\begin{array}{l}7 \\
10 \\
5 \\
28 \\
\end{array}$ & $\begin{array}{l}14.0 \\
20.0 \\
10.0 \\
56.0 \\
\end{array}$ & $22(44.0 \%)$ \\
\hline Fibrosis & $\begin{array}{l}\text { Yes } \\
\text { No }\end{array}$ & $\begin{array}{l}11 \\
39 \\
\end{array}$ & $\begin{array}{l}22.0 \\
78.0\end{array}$ & \\
\hline
\end{tabular}


Table 3: Characteristics of $\mathrm{H}$ pylori + ve and $\mathrm{H}$ pylori -ve stool patients:

\begin{tabular}{|c|c|c|c|c|}
\hline Studied groups & $\begin{array}{l}\mathrm{GI}(\text { H pylori }+\mathrm{ve}) \\
\text { No. }=20 \quad(100 \%)\end{array}$ & $\begin{array}{l}\text { GII }(\text { H pylori }-\mathrm{ve}) \\
\text { No. }=30 \quad(100 \%)\end{array}$ & $\begin{array}{l}\text { Signifi- } \\
\text { cance }\end{array}$ & $P$. \\
\hline Age (years) Mean ( \pm SD) & $44.2 \pm 9.4$ & $41.5 \pm 12$ & $\mathrm{~T} .=0.8$ & 0.4 \\
\hline $\begin{array}{l}\text { Female } \\
\text { Male }\end{array}$ & $\begin{array}{l}(80.0 \%) \\
(20.0 \%)\end{array}$ & $\begin{array}{l}(83.3 \%) \\
(16.7 \%)\end{array}$ & $\mathrm{X}^{2}=0.09$ & 0.8 \\
\hline $\begin{array}{l}\text { Rural residence } \\
\text { Urban residence }\end{array}$ & $\begin{array}{lc}7 & (35 \%) \\
13 & (65 \%)\end{array}$ & $\begin{array}{l}(53.3 \%) \\
(46.6 \%)\end{array}$ & $X^{2}=0.7$ & 0.4 \\
\hline BMI mean $\left(\mathrm{Kg} / \mathrm{m}^{2} \pm \mathrm{SD}\right)$ & $31.7 \pm 7.8$ & $27.1 \pm 6.3$ & T. $=2.3$ & $0.02 *$ \\
\hline Cholesterol level mean $(\mathrm{mg} / \mathrm{dl} \pm \mathrm{SD})$ & $177.8 \pm 44$ & $247 \pm 47$ & $\mathrm{~T} .=1.2$ & 0.2 \\
\hline Triglyceride level mean $(\mathrm{mg} / \mathrm{dl} \pm \mathrm{SD})$ & $127 \pm 56$ & $116 \pm 49$ & $\mathrm{~T} .=0.7$ & 0.5 \\
\hline $\begin{array}{ll}\text { Mucosal erosion } & +\mathrm{ve} \\
\text { Mucosal erosion } & \text {-ve }\end{array}$ & $\begin{array}{ll}13 & (65.0 \%) \\
7 & (35.0 \%)\end{array}$ & $\begin{array}{l}(26.7 \%) \\
(73.3 \%)\end{array}$ & $\mathrm{X}^{2}=7$ & $0.007 *$ \\
\hline $\begin{array}{l}\text { Mucosal atrophy +ve } \\
\text { Mucosal atrophy -ve }\end{array}$ & $\begin{array}{ll}13 & (65.0 \%) \\
7 & (35.0 \%)\end{array}$ & $\begin{array}{l}(30.0 \%) \\
(70.0 \%)\end{array}$ & $X^{2}=6$ & $0.02 *$ \\
\hline $\begin{array}{l}\text { Mucosal Hyperplasia +ve } \\
\text { Mucosal Hyperplasia -ve }\end{array}$ & $\begin{array}{ll}8 & (40.0 \%) \\
12 & (60.0 \%)\end{array}$ & $\begin{array}{l}(33.3 \%) \\
(66.7 \%)\end{array}$ & $\mathrm{X}^{2}=0.2$ & 0.6 \\
\hline $\begin{array}{ll}\text { Metaplasia } & +v e \\
& -v e\end{array}$ & $\begin{array}{l}(15.0 \%) \\
(85.0 \%)\end{array}$ & $\begin{array}{l}(6.7 \%) \\
(93.3 \%)\end{array}$ & $X^{2}=1$ & 0.3 \\
\hline Dysplasia & $\begin{array}{c}(10.0 \%) \\
(90.0 \%)\end{array}$ & $\begin{array}{l}(3.3 \%) \\
(94.7 \%)\end{array}$ & $X^{2}=0.9$ & 0.3 \\
\hline $\begin{array}{l}\text { Lymphoid Infiltration +ve } \\
\text { Lymphoid Infiltration-ve }\end{array}$ & $\begin{array}{l}(35.0 \%) \\
(65.0 \%)\end{array}$ & $\begin{array}{l}(16.7 \%) \\
(83.3 \%)\end{array}$ & $X^{2}=4$ & 0.2 \\
\hline $\begin{array}{l}\text { Musculosa Hypertrophy+ve } \\
\text { Musculosa Hypertrophy-ve }\end{array}$ & $\begin{array}{c}(40.0 \%) \\
(60.0 \%)\end{array}$ & $\begin{array}{l}(46.7 \%) \\
(53.3 \%)\end{array}$ & $\mathrm{X}^{2}=0.2$ & 0.6 \\
\hline $\begin{array}{cl}\text { Fibrosis } & +\mathrm{ve} \\
& -\mathrm{ve}\end{array}$ & $\begin{array}{l}(4.0 \%) \\
(20.0 \%)\end{array}$ & $\begin{array}{l}(23.3 \%) \\
(76.7 \%)\end{array}$ & $\mathrm{X}^{2}=0.08$ & 0.8 \\
\hline
\end{tabular}

Table 4: Comparison between patients with $H$ pylori + ve and $H$ pylori -ve in tissue:

\begin{tabular}{|c|c|c|c|c|}
\hline Studied groups & $\begin{array}{l}\text { H pylori }+ \text { ve } \\
\text { No. }=19 \quad(100 \%)\end{array}$ & $\begin{array}{c}\text { H pylori }- \text { ve } \\
\text { No. }=31 \quad(100 \%)\end{array}$ & Significance & $P$. \\
\hline Age (years) Mean ( \pm SD) & $46.2 \pm 9$ & $40.4 \pm 11$ & T. $=1.9$ & 0.07 \\
\hline $\begin{array}{l}\text { Female } \\
\text { Male }\end{array}$ & $\begin{array}{l}(78.9 \%) \\
(21.1 \%)\end{array}$ & $\begin{array}{c}(83.9 \%) \\
(16.1 \%)\end{array}$ & $X^{2}=0.2$ & 0.6 \\
\hline $\begin{array}{l}\text { Rural residence } \\
\text { Urban residence }\end{array}$ & $\begin{array}{cc}6 & (31.5 \%) \\
13 & (68.4 \%)\end{array}$ & $\begin{array}{l}(51.6 \%) \\
(48.4 \%)\end{array}$ & $X^{2}=0.7$ & 0.4 \\
\hline BMI mean $\left(\mathrm{Kg} / \mathrm{m}^{2} \pm \mathrm{SD}\right)$ & $30.6 \pm 8.6$ & $28 \pm 6$ & $\mathrm{~T} .=1.3$ & 0.2 \\
\hline Cholesterol level mean $(\mathrm{mg} / \mathrm{dl} \pm \mathrm{SD})$ & $179 \pm 57$ & $244 \pm 74$ & $\mathrm{~T} .=1$ & 0.3 \\
\hline Triglyceride level mean $(\mathrm{mg} / \mathrm{dl} \pm \mathrm{SD})$ & $125 \pm 55$ & $118 \pm 50$ & T. $=0.4$ & 0.7 \\
\hline $\begin{array}{ll}\text { Mucosal erosion } & +\mathrm{ve} \\
\text { Mucosal erosion } & \text {-ve }\end{array}$ & $\begin{array}{cc}13 & (68.4 \%) \\
6 & (31.6 \%)\end{array}$ & $\begin{array}{l}(25.8 \%) \\
(74.2 \%)\end{array}$ & $X^{2}=9$ & $0.003^{*}$ \\
\hline $\begin{array}{l}\text { Mucosal atrophy +ve } \\
\text { Mucosal atrophy -ve }\end{array}$ & $\begin{array}{ll}12 & (63.2 \%) \\
7 & (36.8 \%)\end{array}$ & $\begin{array}{l}(32.3 \%) \\
(67.7 \%)\end{array}$ & $X^{2}=4.5$ & $0.03 *$ \\
\hline $\begin{array}{l}\text { Mucosal Hyperplasia +ve } \\
\text { Mucosal Hyperplasia -ve }\end{array}$ & $\begin{array}{l}(57.9 \%) \\
(42.1 \%)\end{array}$ & $\begin{array}{l}(22.6 \%) \\
(77.4 \%)\end{array}$ & $X^{2}=6$ & $0.012 *$ \\
\hline $\begin{array}{ll}\text { Metaplasia } & +v e \\
\text { Metaplasia } & \text {-ve }\end{array}$ & $\begin{array}{l}(26.3 \%) \\
(73.7 \%)\end{array}$ & $\begin{array}{l}(0.0 \%) \\
(100 \%)\end{array}$ & $X^{2}=9$ & $0.003 *$ \\
\hline $\begin{array}{ll}\text { Dysplasia } & +\mathrm{ve} \\
\text { Dysplasia } & -\mathrm{ve}\end{array}$ & $\begin{array}{l}(10.5 \%) \\
(89.5 \%)\end{array}$ & $\begin{aligned}(3.2 \%) \\
(96.8 \%)\end{aligned}$ & $X^{2}=1.1$ & 0.3 \\
\hline $\begin{array}{l}\text { Lymphoid Infiltration }+ \text { ve } \\
\text { Lymphoid Infiltration }- \text { ve }\end{array}$ & $\begin{array}{l}(42.1 \%) \\
(57.9 \%)\end{array}$ & $\begin{array}{l}(12.9 \%) \\
(87.1 \%)\end{array}$ & $X^{2}=7$ & $0.02 *$ \\
\hline $\begin{array}{l}\text { Musculosa Hypertrophy +ve } \\
\text { Musculosa Hypertrophy -ve }\end{array}$ & $\begin{array}{l}(42.1 \%) \\
(57.9 \%)\end{array}$ & $\begin{array}{l}(45.2 \%) \\
(54.8 \%)\end{array}$ & $X^{2}=0.05$ & 0.8 \\
\hline $\begin{array}{lc}\text { Fibrosis } & +\mathrm{ve} \\
\text { Fibrosis } & -\mathrm{ve}\end{array}$ & $\begin{array}{l}(26.3 \%) \\
(73.7 \%)\end{array}$ & $\begin{array}{l}(19.4 \%) \\
(80.6 \%)\end{array}$ & $\mathrm{X}^{2}=0.3$ & 0.6 \\
\hline
\end{tabular}


Table 5: Correlation between $H$. pylori-specific antigens in stool and in tissue:

\begin{tabular}{|c|l|}
\hline H. pylori- in tissue & H. pylori-specific antigens in stool \\
\hline$r$. & 0.5 \\
\hline$p$. & $0.000^{*}$ \\
\hline
\end{tabular}

In140 patients with chronic calcular cholecystitis, the rapid urease test was positive in gallbladder mucosa of 35 patients $(25 \%)$, and negative in 105 patients $(75 \%)$ while on histological examination after modified Geimsa staining, H. pylori-like bacteria were in 89 patients $(63.6 \%)$. They concluded that $H$. pylori was present in the gallbladder mucosa in patients with chronic calcular cholecystitis as an etiological cause of chronic inflammation.

In the present study, histopathologically, the most predominant finding was musculosa hypertrophy (44\%), mucosal atrophy $(42 \%)$, mucosal erosion (42\%), lymphoid aggregates all over mucosa (24\%), while gallbladder wall fibrosis (22\%). Mucosal hyperplasia was in $36 \%$, metaplasia was in $10 \%$ and dysplasia was in $6 \%$.

Misran et al. (2007) assessed the prevalence of $H$. pylori in patients with gastric carcinoma and correlate it with gross appearance and histological type. They found a significant association between $H$. pylori and grades of gastritis $(\mathrm{P}<0.01)$ in controls as well as in patients but it failed to show a significant association with tumor grades, intestinal metaplasia, tumor site and patients' ages. So, prevalence of $H$. pylori infection was not directly associated with pathogenesis of gastric cancer but it may act as a co-carcinogen by damaging the mucosa and thereby making it more susceptible to effects of carcinogen

In the present study, there was no significant difference between $H$. pylori $\mathrm{Ag}+\mathrm{ve}$ and -ve in stool as regard histopathological changes except for mucosal erosion and mucosal atrophy that showed significant difference between the two groups $(\mathrm{p}=0.007 \&$ 0.02 respectively). Jeongmin et al. (2011) evaluated stool antigen test for the detection of $H$. pylori in comparison with histology, rapid urease test, 13C-urea breath test, and serology found that sensitivity, specificity, positive and negative predictive values, and accuracy of stool antigen test were $93.1 \%$, $94.6 \%, 95.1 \%, 92.3 \%, \& 93.8 \%$, respectively. The sensitivity of histology, rapid urease test, and 13C-urea breath test ranged from $89.1 \%$ to $97.6 \%$, specificity was $>98 \%$, and serology had high sensitivity, but low specificity. The accuracy of the stool antigen test was comparable to that of other methods (93.6-95.9\%), whereas it was higher than that of serology.

In the present study, comparison between patients with $H$. pylori +ve in tissue and -ve in tissue, showed statistically significant differences as regard histopathological changes in mucosal erosions $(p=0.003)$, mucosal atrophy $(\mathrm{p}=0.03)$, mucosal hyperplasia $(\mathrm{p}=0.012)$, metaplasia $(\mathrm{p}=0.003)$ and lymphoid infiltration $(\mathrm{p}=0.02)$. De Moricz et al. (2010) reported that gallbladders with metaplasia and follicles displayed statistically significant contrasts when associated with lymphoid follicles in the mucosa of gallbladder (follicular cholecystitis) and the existence of bacilli.

Misra et al. (2007) emphasized that preneoplastic histological changes were in the gallbladder mucosa, restricted to infection with Helicobacter spp., for instance, intestinal metaplasia, hyperplasia, dysplasia, eosinophilic inflammation, and hyalinosis. Also, Dong-Feng et al. (2007) reported that metaplasia provided suitable conditions for $H$. pylori colonization in gallbladder. By EM revealed at sites infected with $H$. pylori, the integrity of the cell-to-cell membrane of gallbladder epithelium was destructed, with swelling of mitochondria and dilatation of endoplasmic reticulum. In $H$. pylori-infected gallbladder mucosa, metaplasia lesions area accompanying with $H$. pylori colonization 
could be detected in $91.5 \%$ of the specimens. The morphological data may indicate a potential direction for determining the role of $H$. pylori in the formation of metaplasia.

Generally speaking, in Egypt Aziz et al. (2015) stated that on dealing with waterborne infections, one might give priority to infectious diseases with high mortality such as cholera and other diarrheal diseases. However, H. pylori might cause cancer especially in elderly patients and given that life expectancy has increased, and so poverty, preventing infection-associated cancers (e.g., H. pylori and hepatitis C) should be a priority of health organizations in the decades to come.

\section{Conclusion}

Helicobacter pylori Ag in stool is a simple, reliable non-invasive technique should be applied for detection of $H$. pylori infection in chronic calcular cholecystitis and to monitor the success of eradication treatment.

The data proved that $H$. pylori infection could be one of the etiological factors of cholecystolithiasis. Helicobacter pylori correlated with gallbladder premalignant lesions including atrophy, hyperplasia, metaplasia and lymphoid infiltration. The precise mechanism requires further research.

\section{Recommendations}

1- Epidemiological studies are indicated to cover Egyptian districts with special attention to socioeconomic status, other associated organisms, other associated diseases, environmental factors exploration and genetic factors.

2-H. pylori eradication is a must especially in childhood. Also, other co-parasites and/or micro-organisms, if present must be diagnosed and treated as well.

3- Experimental studies are needed to explore behavior, etiology and host-parasite relationship of $H$. pylori.

\section{References}

Apostolov, E, Al-Soud, WA, Nisson, I, Kornilovska, I, Usenko, V, et al, 2005:Helicobacter pylori and other Helicobacter species in gallbladder and liver of patients with chronic chole- cystitis by immunological and molecular methods. Scand. J. Gastroenterol. 40, 1:96-102.

Aziz RK, Khalifa M, Sharaf R, 2015: Contaminated water as a source of Helicobacter pylori infection: a review. J. Adv. Res. 6, 4:539-47.

Cintia, PS, Carlos JP, Oliviera AG, Guerra, JB, Marques DL, et al, 2003: .Association of the presence of Helicobacter in gallbladder tissue with cholelithiasis and cholecystitis. J. Clin. Microbiol. 41, 12:5615-8.

De Moricz, A, Melo, M, Castro, AM, de Campos, T, Silva, RA, et al, 2010: Prevalence of Helicobactersp in chronic cholecystitis and correlation with changes on the histological pattern of the gallbladder. Acta Cir. Bras. 25, 3:218-24.

Dong-Feng, C, Hu, L, Yi, P, et al, 2007:H. pylori are associated with chronic cholecystitis. World J. Gastroenterol. 13, 7:1119-22.

El-Fakhfakh, EA, Montasser, IF, Khalifa, RA, 2014: Evaluation of salivary and serum anti-Helicobacter pylori in Egyptian patients with $H$. pylori related gastric disorders. J. Egypt. Soc. Parasitol. 44, 1:275-83.

El-Omar, EM, Penman, ID, Ardill, JES, Chittajallu, RS, Howie, C, et al, 1995:Helicobacter pylori infection and abnormalities of acid secretion in patients with duodenal ulcer disease. Gastroenterol.109:681-91

Fekry, AA, Kassem, AA, Shahin, D, Shabana, Hosam, AS, Mostafa, S, 2014:Helicobacter pylori infection in patients with chronic calcularcholecystitis a cross- sectional study. J. Surg, 2, 4:58-62.

Ghzal, A, Elsabbagh, N, El-Riwini, M, 2001: Presence of Helicobacter sp.DNA in the gallbladder of Egyptian patients with gallstone diseases. EMHJ. 17, 12:925-9.

Gisbert, JP, de la Morena, F, Abraira, V, 2006: Accuracy of monoclonal stool antigen test for the diagnosis of $H$. pylori infection: A systematic review and meta-analysis. Am. J. Gastroenterol. 101:1921-30.

Gisbert, JP, Pajares, JM, 2004: Stool antigen test for diagnosis of Helicobacter pylori infection: a systematic review. Helicobacter 9:347-68 Hansen, S, Melby, KK, Aase, S, Jellum, E, Vollset, SE, 1999: Helicobacter pylori infection and risk of cardia cancer and non-cardia gastric cancer: a nested case-control study. Scand. J. Gastroenterol. 34:353-60

Jeongmin, C, Kim, C.H, Kim, D, Chung, SJ, Song, JH, et al, 2011: Prospective evaluation of 
a new stool antigen test for the detection of $\mathrm{Hel}$ icobacter pylori, in comparison with histol-ogy, rapid urease test, 13C-urea Breath Test, and Serology. J. Gastroenterol. Hepatol. 26, 6:1053-9.

Kawaguchi, M, Saito, T, Ohno, H, et al, 1996: Bacteria closely resembling Helicobacter pylori detected immunohistochemically and genetically in resected gallbladder mucosa. J. Gastroenterol 31, 2:294-8.

Lee, JW, Lee, DH, Lee, JI, Jeong, S, Kwon, K S, et al, 2010: Identification of Helicobacter pylori in gallstone, bile, and other hepatobiliary tissues of patients with cholecystitis. Gut Liver 4: 60-7.

Misra, V, Misra, SP, Dwivedi, M, Shouche, Y, Dharne, M, et al, 2007: Helicobacter pylori in areas of gastric metaplasia in the gallbladder and isolation of $H$. pylori DNA from gall-stones. Pathol. 39, 4:419-24.

Murphy, G, Michel, A, Taylor, PR, Albanes, D, Weinstein, SJ, et al, 2014: Association of seropositivity to Helicobacter species and biliary tract cancer inthe ATBC study. Hepatology 60, 6:1963-71.

Parsonnet, J, Hansen, S, Rodriguez, L, et al, 1994:Helicobacter pylori and gastric lymphoma. N. Engl. J. Med. 330:1267-71

Warren, JR, Marshall, BJ, 1983: Unidentified curved bacilli on gastric epithelium in active chronic gastritis. Lancet 1:1273-5.

WGO, 2011: World Gastroenterology Organization; world gastroenterology organization global guidelines: helicobacter pylori in developing countries. J. Digest. Dis. 12:319-26

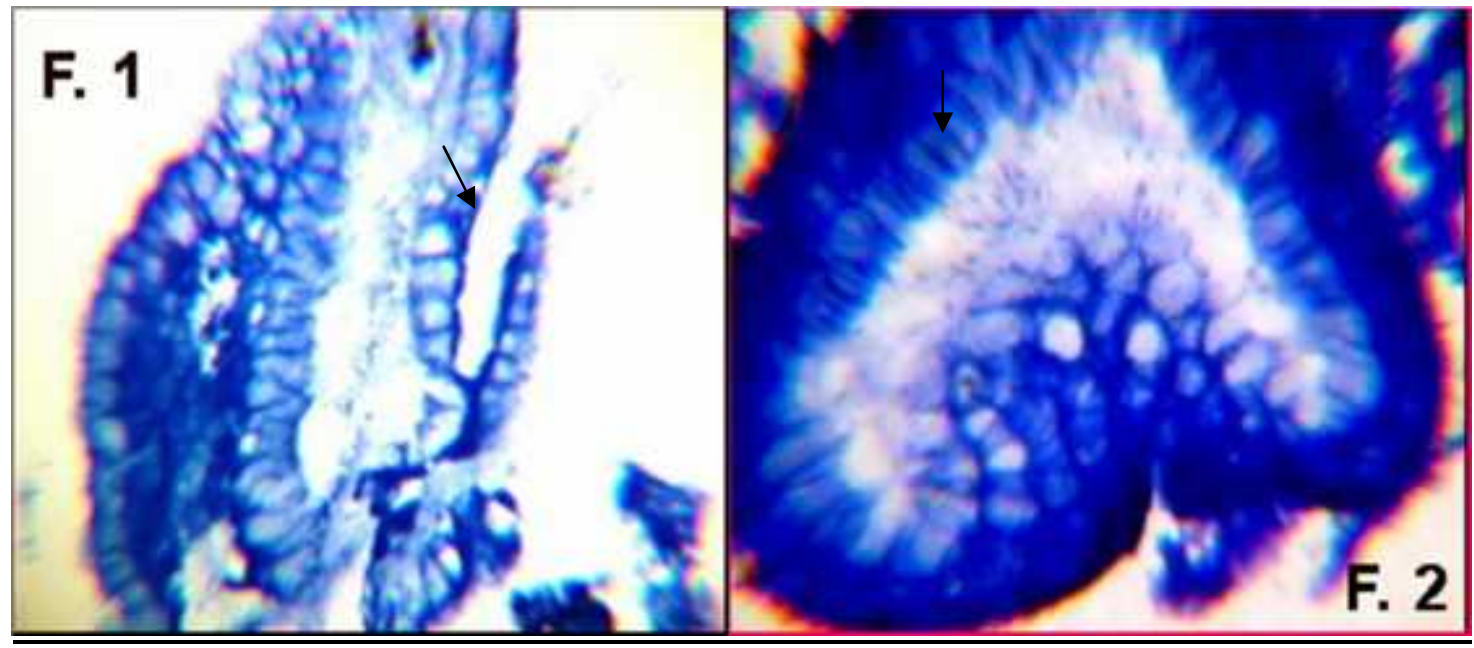

Figs: 1,2 Gallbladder mucosa with positive H. pylori like (arrow head) in glands lumen (Giemsa stain X-400).

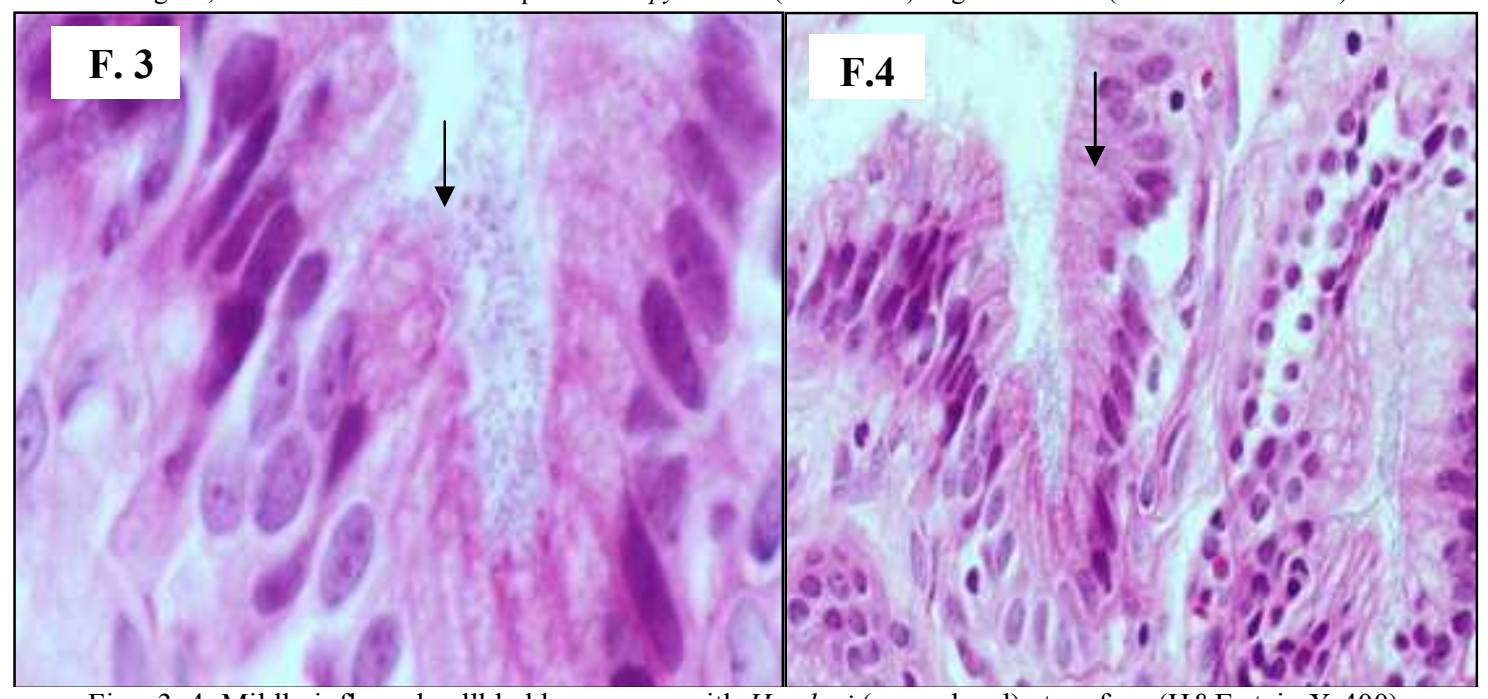

Figs. 3, 4: Mildly inflamed gallbladder mucosa with $H$ pylori (arrow head) at surface (H\&E stain X-400) 